\title{
Psychosocial aspect of quality of life among working and unemployed nurses and midwives
}

\author{
Marta Czekirda', Paweł Chruściel', Noemi Czekirda², Mirosław J Jarosz ${ }^{3,4}$ \\ ${ }^{1}$ Department of Basic Nursing and Medical Teaching, Faculty of Health Sciences, University of Lublin, Poland \\ ${ }^{2}$ Center of Oncology of Lublin Region, Lublin, Poland \\ ${ }^{3}$ Faculty of Health Sciences, University of Economics and Innovation, Lublin, Poland \\ ${ }^{4}$ Department of Biostatistics, Demography and Epidemiology, Institute of Rural Health in Lublin, Poland
}

Czekirda M, Jarosz MJ, Chruściel P. Psychosocial aspect of quality of life among working and unemployed nurses and midwives. Ann Agric Environ Med. 2017; 24(3): 472-476. doi: 10.5604/12321966.1235172

\begin{abstract}
Objective. The objective of the study was to explain differences in the subjective evaluation of the psychological and social aspects of quality of life in a group of working and unemployed nurses and midwives.

Materials and method. The survey was conducted in a group of 620 professionally-active and inactive people (315 nurses and 305 midwives), selected by random stratified-systematic sampling. The tool used to gather empirical material was the standardized questionnaire WHOQoL-100.

Results. Professionally-active nurses evaluated the mental domain less favourably $(\mathrm{M}=12.33)$, compared with unemployed nurses $(M=12.73)$, and the difference between average values was statistically significant $(p=.043)$. It is also worth noting that in the group of midwives there were significant differences in each discussed domain. The unemployed respondents evaluated more positively the overall quality of life $(M=14.29 ; p=.005)$ and the mental domain $(M=12.85 ; p=.009)$, while the social domain was evaluated less favourably by the professionally-active midwives $(M=12.73 ; p=.022)$.

Conclusions. Paradoxically, those who were unemployed made slightly more positive evaluations in comparison with the professionally active. Professional work is not a factor preferably affecting the quality of life and its psychosocial dimension. The higher quality of life of the unemployed respondents may result from the buffering impact of social support.
\end{abstract}

\section{Key words}

quality of life, nurses, midwife, unemployment

\section{INTRODUCTION}

The notion of life quality comprises various elements, such as: material goods, safety, including economic security, health, membership of certain social groups, and environment. Each of these elements can be considered in the objective context, but evaluation of life quality depends on the subjective level of fulfilling the needs in each of these domains. The applied methods of survey and interpretation of results concerning the discussed phenomenon vary among particular branches of science. In spite of various research tools, no single definition of life quality has been drawn up to-date, and problems with the meaning result from the multi-aspect character of this concept $[1,2]$. Nevertheless, quality of life is largely a subjective value and depends substantially on the mental state, personality, or system of values of a given person.

One of the factors influencing human life in our civilisation is professional work which is the basis of a person's existence [3]. The outcome of work is not only creation of material goods but also the shaping of life quality. Professional work contributes to well-being and, according to the authors, is the basis of self-identity, especially for middle-aged people $[4,5]$.

In the system of values of a contemporary human, professional work has considerable significance as the basic form of activity for an adult, a measure of achievements,

Address for correspondence: Marta Czekirda, Department of Basic Nursing and Medical Teaching, Faculty of Health Sciences, University of Lublin, Poland E-mail: marta-czekirda@wp.pl

Received: 26 October 2014; accepted: 17 March 2015; first published: February 2017 security and quality of life $[3,6]$. On the other hand, lack of work is one of the reasons for deteriorated mental condition associated with new demands and the need to adapt to this situation. Unemployment changes previous relations with the environment, cuts-off the advantages connected with professional work, frequently alters the position in the family and among friends, and influences one's views on ethics, religion or politics $[7,8]$.

Research on life quality of people who have lost their jobs due to various reasons, or have never been employed, demonstrates that their life is not the same as the life of working people. This is a completely different way of functioning, connected with another system of values and possibilities. Thus, it seems that the phenomena of unemployment and an insufficient number of nurses and midwives in Poland are basically shaped by issues connected with the broadly understood quality of life of people pursuing these professions.

Research on the life quality of medical staff frequently takes into account the physical aspect, related to efficiency of basic physiological functions. An increasing number of patients who are elderly or need intensive care, as well as work in a forced position or at night, negatively influence the physical state of medical employees [9-13]. Deficits in this area cause characteristic symptoms in the emotional sphere, such as mood changes, anxiety, proneness to depression, over-sensitivity and lack of self-control [14].

The presented study focuses on the psychological and social aspects, due to the specific character of the work, of nurses and midwives who are exposed to imbalances in these domains. 
Apart from the detrimental physical factors, nurses and midwives are susceptible to tiredness, sleep disturbances and stress [15]. Constant availability, bearing responsibility for the health and life of patients, as well as stress connected with witnessing death and suffering, enhance negative feelings. Consequently, physical workload is accompanied by mental strain exerting a direct influence on the psychosocial domain of life quality.

\section{OBJECTIVE}

This study attempts to explain differences in the subjective evaluation of the psychological and social aspects of quality of life in the group of nurses and midwives.

\section{MATERIALS AND METHOD}

Examined group and selection. The general examined population comprised nurses and midwives from the Lublin province in eastern Poland. The sampling frame was based on reports of the Main Chamber of Nurses and Midwives and on registers of the Regional Labour Office in Lublin. In order to select the examined group and to enhance its representative character, random stratified-systematic sampling was applied. Stratified sampling was used to select health care centres and Labour Offices, whereas systematic sampling was applied to determine the number of respondents in particular institutions.

The selection encompassed a total of 1,200 nurses, who were professionally-active or unemployed nurses and midwives from the city of Lublin, and the following towns in Lublin Province: Puławy, Świdnik, Hrubieszów, Lubartów, Zamość, Kraśnik, Parczew, Włodawa, Radzyń Podlaski, Janów Lubelski, Chełm, Łuków, Międzyrzec Podlaski and Łęczna.

The research had the character of diagnostic survey. The respondents received anonymous questionnaires and were asked to fill them in and send them to a given address. On the basis of the returned questionnaires, 620 respondents (315 nurses and 305 midwives) were qualified for the study; the remaining questionnaires were not sent back or had significant gaps. Among the 315 nurses, 144 were professionally-active, while among the 305 midwives - 157 were professionally-active.

In the group of nurses there were only 6 men (1.9\%) and in the group of midwives - just 2 men (0.7\%). Due to such a small share of males, no statistical analysis in relation to gender was carried out.

The study was approved by the Bioethical Commission at the Medical University of Lublin (Permit No. KE024/71/2016).

Measurement tool. The applied research tool was generic questionnaire WHOQOL-100 [16], supplemented with a set of demographic questions. In the introduction to the questionnaire, the respondents were familiarised with the purpose of the study and asked to complete the questionnaire thoroughly, and were guaranteed anonymity.

The first part of the questionnaire contained questions for creating a profile of the overall quality of life, general health and 6 domains of life quality:

- physical (pain, discomfort, sleep, rest, energy, tiredness);
- psychological/mental (appearance, self-confidence, positive and negative feelings, perception of one's own body, self-esteem);

- social (social support, personal relationships, sexual activity);

- environment (security, material resources, access to health care, access to information, spare time);

- independence (dependence on medication, work/learning ability, mobility);

- spiritual (importance of faith and religion in life, significance of faith in dealing with problems).

The independent variable was a respondent's declaration as a working or an unemployed person. Dependent variables which could modify the relation: quality of life - occupational status were: age, marital status, place of residence and education. Overall quality of life was also evaluated.

Raw scores of the examined individuals were presented on a scale of 4-20 (irrespective of overall quality of life measured on a scale of $1-5)$.

Statistical analysis. The results of the research were statistically analysed with SPSS software. The choice of the statistical methods used in the study was conditioned by the kind of data contained in the questionnaire. Descriptive statistics were calculated for quantitative variables, while parametric Student's t-test for independent variables was used to test the significance of differences between average values, with checking of equality of variances by Levene's test. For analysis of dependences of qualitative features, multifield Tables and non-parametric Chi-square test were used (if necessary - calculated with Yates' correction), as well as Fisher's exact test. The outcomes of tests $\mathrm{p}<.05$ were regarded as statistically significant. Furthermore, at interpretation of extended frequency Tables the Parteo principle was taken into account, also known as the 20:80 rule, according to which $20 \%$ of the respondents represented $80 \%$ of the examined phenomenon.

\section{RESULTS}

The average age in the examined group of nurses was 42.6 (for the unemployed nurses - 33.8), whereas in the group of midwives it was 41.2 (for the unemployed midwives - 30.4). There was a noticeable majority of younger people in the group of unemployed nurses (age 26-35) and midwives (age 18-30).

Both in the group of nurses and midwives, most people were in a relationship, lived in towns and had secondary education (Tab. 1).

The analysis demonstrates that overall quality of life was evaluated as satisfactory by the respondents both in the group of nurses and midwives. It is worth noting that unemployed midwives rated this variable higher $(M=14.29)$ than working midwives $(M=13.55)$. In the case of working nurses, the situation was the opposite (Tabs. 2, 4).

Furthermore, the mental and social domains were evaluated more favourably by unemployed midwives $(\mathrm{M}=12.85 ; \mathrm{M}=13.17)$ than by nurses from the same group $(\mathrm{M}=12.73 ; \mathrm{M}=12.74)$.

The evaluations assigned by the respondents to particular domains of life quality were similar. However, those who 
Table 1. Demographic characteristics of the study group

\begin{tabular}{|c|c|c|c|c|c|c|c|c|c|}
\hline \multirow{3}{*}{ Variable } & & \multicolumn{4}{|c|}{ Nurses } & \multicolumn{4}{|c|}{ Midwives } \\
\hline & & \multicolumn{2}{|c|}{ Working } & \multicolumn{2}{|c|}{ Unemployed } & \multicolumn{2}{|c|}{ Working } & \multicolumn{2}{|c|}{ Unemployed } \\
\hline & & $\mathbf{N}$ & $\%$ & $\mathbf{N}$ & $\%$ & $\mathbf{N}$ & $\%$ & $\mathbf{N}$ & $\%$ \\
\hline \multirow{9}{*}{ Age } & $\begin{array}{l}18-25 \\
\text { years }\end{array}$ & 6 & 4.2 & 24 & 14 & 16 & 10.2 & 44 & 29.7 \\
\hline & $\begin{array}{l}26-30 \\
\text { years }\end{array}$ & 17 & 11.8 & 45 & 26,3 & 24 & 15.3 & 42 & 28.4 \\
\hline & $\begin{array}{l}31-35 \\
\text { years }\end{array}$ & 25 & 17.4 & 44 & 25.7 & 21 & 13.4 & 26 & 17.6 \\
\hline & $\begin{array}{l}36-40 \\
\text { years }\end{array}$ & 31 & 21.5 & 30 & 17.5 & 53 & 33.8 & 15 & 10.1 \\
\hline & $\begin{array}{l}41-45 \\
\text { years }\end{array}$ & 30 & 20.8 & 17 & 9.9 & 37 & 23.6 & 3 & 2.0 \\
\hline & $\begin{array}{l}46-50 \\
\text { years }\end{array}$ & 25 & 17.4 & 7 & 4.2 & 2 & 1.3 & 16 & 10.8 \\
\hline & $\begin{array}{l}51-55 \\
\text { years }\end{array}$ & 3 & 2.1 & 4 & 2.4 & 4 & 2.4 & 2 & 1.4 \\
\hline & $\begin{array}{l}56-60 \\
\text { years }\end{array}$ & 7 & 4.8 & 0 & 0 & 0 & 0 & 0 & 0 \\
\hline & $\Sigma$ & 144 & 100 & 171 & 100 & 157 & 100 & 148 & 100 \\
\hline \multirow{5}{*}{$\begin{array}{l}\text { Marital } \\
\text { status }\end{array}$} & Single & 15 & 10.4 & 31 & 18.1 & 30 & 19.1 & 52 & 35.1 \\
\hline & Married & 115 & 79.9 & 121 & 70.8 & 119 & 75.8 & 82 & 55.4 \\
\hline & Widow & 12 & 8.3 & 15 & 8.8 & 5 & 3.2 & 13 & 8.8 \\
\hline & Divorcee & 2 & 1.4 & 4 & 2.3 & 3 & 1.9 & 1 & 0.7 \\
\hline & $\Sigma$ & 144 & 100 & 171 & 100 & 157 & 100 & 148 & 100 \\
\hline \multirow{3}{*}{$\begin{array}{l}\text { Place of } \\
\text { residence }\end{array}$} & City/Town & 108 & 75.0 & 106 & 62.0 & 119 & 75.8 & 106 & 71.6 \\
\hline & Rural areas & 36 & 25.0 & 65 & 38.0 & 38 & 24.2 & 42 & 28.4 \\
\hline & $\Sigma$ & 144 & 100 & 171 & 100 & 157 & 100 & 148 & 100 \\
\hline \multirow{3}{*}{ Education } & Secondary & 126 & 87.5 & 131 & 76.6 & 129 & 82.2 & 91 & 61.5 \\
\hline & Higher & 18 & 12.5 & 40 & 23.4 & 28 & 17.8 & 57 & 38.5 \\
\hline & $\boldsymbol{\Sigma}$ & 144 & 100 & 171 & 100 & 157 & 100 & 148 & 100 \\
\hline
\end{tabular}

were professionally-inactive made slightly better evaluations in comparison with those who were working.

Professionally-active nurses evaluated the mental domain less favourably $(\mathrm{M}=12.33)$ in comparison with unemployed nurses $(M=12.73)$, and the difference in average values was statistically significant ( $\mathrm{p}=.043$ ) (Tabs. 2, 3).

In the group of midwives there were considerable differences in each discussed domain. Unemployed respondents evaluated overall quality of life $(\mathrm{M}=14.29 ; \mathrm{p}=.005)$ and mental domain $(\mathrm{M}=12.85 ; \mathrm{p}=.009)$ more favourably. The social domain was evaluated lower by professionally-active midwives $(\mathrm{M}=12.73 ; \mathrm{p}=.022)$ (Tabs. 4, 5).

Table 2. Quality of life of nurses, depending on occupational status

\begin{tabular}{llcccc}
\hline Domain & Occupational status & $\mathrm{N}$ & $\mathrm{M}$ & $\mathrm{SD}$ & $\mathrm{SE}$ \\
\hline \multirow{2}{*}{ Overall quality of life } & Working & 144 & 14.06 & 2.22 & .18 \\
\cline { 2 - 6 } & Unemployed & 168 & 13.90 & 2.41 & .19 \\
\hline \multirow{2}{*}{ Mental domain } & Working & 103 & 12.33 & 1.59 & .16 \\
\cline { 2 - 6 } & Unemployed & 136 & 12.73 & 1.46 & .12 \\
\hline \multirow{2}{*}{ Social domain } & Working & 138 & 12.66 & 1.87 & .16 \\
\cline { 2 - 6 } & Unemployed & 162 & 12.74 & 1.74 & .14 \\
\hline
\end{tabular}

$\mathrm{N}$ - number; $\mathrm{M}$ - average; SD - standard deviation; SE - statistical error
Table 3. Difference in the quality of life of nurses according to their occupational status

\begin{tabular}{|c|c|c|c|c|c|c|c|}
\hline \multirow{2}{*}{ Domain } & \multicolumn{2}{|c|}{ Levene's test } & \multicolumn{5}{|c|}{ Student's t-test equality of means } \\
\hline & $\mathrm{F}$ & $\mathrm{p}$ & $\mathrm{t}$ & df & $\mathrm{p}$ & Difference & SE \\
\hline \multirow{2}{*}{ Overall quality of life } & \multirow{2}{*}{.720} & \multirow{2}{*}{.397} & .598 & 310 & .550 & \multirow{2}{*}{.16} & .26 \\
\hline & & & .602 & 308.41 & .548 & & .26 \\
\hline \multirow{2}{*}{ Mental domain } & \multirow{2}{*}{1.699} & \multirow{2}{*}{.194} & -2.033 & 237 & .043 & \multirow{2}{*}{-.40} & .20 \\
\hline & & & -2.009 & 209.32 & .046 & & .20 \\
\hline \multirow{2}{*}{ Social domain } & \multirow{2}{*}{1.073} & \multirow{2}{*}{.301} & -.347 & 298 & .729 & \multirow{2}{*}{-7.24} & .21 \\
\hline & & & -.345 & 283.27 & .730 & & .21 \\
\hline
\end{tabular}

marked correlations are significant at $\mathrm{p} \leq .05$.

$\mathrm{F}$ - Levene's test; $\mathrm{p}$ - level of significance; $\mathrm{t}$ - Student's t-test; $\mathrm{df}$ - degrees of freedom; SE statistical terror

Table 4. Quality of life of midwives, depending on occupational status

\begin{tabular}{llcccc}
\hline Domain & Occupational status & $\mathrm{N}$ & $\mathrm{M}$ & $\mathrm{SD}$ & $\mathrm{SE}$ \\
\hline \multirow{2}{*}{ Overall quality of life } & Working & 152 & 13.55 & 2.44 & .20 \\
\cline { 2 - 6 } & Unemployed & 147 & 14,29 & 2.04 & .17 \\
\hline \multirow{2}{*}{ Mental domain } & Working & 126 & 12.33 & 1.65 & .15 \\
\cline { 2 - 6 } & Unemployed & 85 & 12.85 & 1,$2 ;$ & .13 \\
\hline \multirow{2}{*}{ Social domain } & Working & 153 & 12.73 & 1.54 & .12 \\
\cline { 2 - 6 } & Unemployed & 137 & 13.17 & 1.68 & .14
\end{tabular}

$\mathrm{N}$ - number, $\mathrm{M}$ - average, SD - standard deviation, SE - statistical error

Table 5. Difference in the quality of life of midwives according to their occupational status

\begin{tabular}{|c|c|c|c|c|c|c|c|}
\hline \multirow{2}{*}{ Domain } & \multicolumn{2}{|c|}{ Levene's test } & \multicolumn{5}{|c|}{ Student's t-test equality of means } \\
\hline & $\mathrm{F}$ & $\mathrm{p}$ & $\mathrm{t}$ & Df & $\mathrm{p}$ & Difference & SE \\
\hline \multirow{2}{*}{$\begin{array}{l}\text { Overall quality } \\
\text { of life }\end{array}$} & \multirow{2}{*}{13.208} & \multirow{2}{*}{.000} & -2.811 & 297 & .005 & \multirow{2}{*}{-.73} & .26 \\
\hline & & & -2.819 & 290.87 & .005 & & .26 \\
\hline \multirow{2}{*}{ Mental domain } & \multirow{2}{*}{10.778} & \multirow{2}{*}{.001} & -2.478 & 209 & .014 & \multirow{2}{*}{-.52} & .21 \\
\hline & & & -2.626 & 207.38 & .009 & & .20 \\
\hline \multirow{2}{*}{ Social domain } & \multirow{2}{*}{1.085} & \multirow{2}{*}{.298} & -2.295 & 288 & .022 & \multirow{2}{*}{-.43} & .19 \\
\hline & & & -2.284 & 276.98 & .023 & & .19 \\
\hline
\end{tabular}

marked correlations are significant at $\mathrm{p} \leq .05$.

$\mathrm{F}$ - Levene's test; $\mathrm{p}$ - level of significance; $\mathrm{t}$ - Student's t-test; $\mathrm{df}$ - degrees of freedom; SE statistical terror

Moreover, the analysis of other domains, not included in this study, showed statistically significant differences in the physical domain $(\mathrm{p}=.01)$ and the independence level $(\mathrm{p}=.005)$ in relation to the group of unemployed nurses - higher evaluations. In the case of unemployed midwives, there were statistically significant correlations in higher evaluation of environment $(\mathrm{p}=.000)$ and independence $(\mathrm{p}=.001)$ domains.

\section{DISCUSSION}

It is generallybelieved that unemployment has an adverse effect on the quality of life and health, and is a factor undermining self-esteem and self-confidence [17-19]. Nevertheless, the presented study demonstrates that evaluation of overall quality of life and its particular domains varied considerably in the groups of nurses and midwives, depending on their occupational status.

It is also worth noting the paradoxically higher quality of life in the mental and social domains among unemployed 
nurses and midwives. In this case, the hypothesis about work as a beneficial factor is not confirmed. As shown by the descriptive analysis, the majority of the unemployed people $(70.8 \%$ of nurses and $55.4 \%$ of midwives) were in a relationship; therefore, the high evaluation of life quality may result from greater support received by the unemployed from family and friends and, as a consequence, certain types of protective behaviour. However, research by Gholami does not confirm this assumption [20]. Furthermore, positive evaluation of life quality by the unemployed may result from their satisfaction with having spare time and considerable freedom, or high self-esteem [18]. This was not confirmed by the study, revealing worse overall quality of life and the mental domain in working nurses, due to depression and other health concerns $[15,20,21]$.

Quality of life significantly correlates with the subjective condition of physical and mental health. Positive evaluation of the latter domain facilitates coping with stress at work, protects from emotional exhaustion and contributes to a positive attitude. On the other hand, negative feelings in the physical domain undermine mental health [22].

A person's quality of life is always a subjective feature, largely dependent on the person's mental state, personality traits, preferences and system of values. The mental domain exerts enormous influence on an individual's functioning within society. It seems that employment should improve evaluation of life quality in this domain and unemployment should have the opposite effect. However, according to the current study, evaluation of life quality in the mental domain was lower in the group of working nurses and midwives than among those who were unemployed. The above-mentioned outcomes are not reflected in the results of research indicating worse mental health in unemployed people [18, 23]. The character of work in health care is associated with high exposure to occupational stress [24, 25]. Emotional demands are especially significant, such as the need to cope with negative feelings resulting from everyday contact with illnesses, difficult situations of life, and sometimes with death of patients. These factors can significantly decrease evaluation of life quality in the mental domain. Nevertheless, literature on the subject offers a psychological profile of an unemployed person: of low self-esteem, dissatisfied with his or her situation, but with a positive goal of finding a job. [4, $20,21]$. Therefore, it can be supposed that since the majority of unemployed respondents are young people, below the age of 35 ( $52 \%$ of nurses and $58.1 \%$ of midwives), they evaluate quality of life in the mental domain less favourably [21, 27]. However, the situation is exactly the opposite, which may result from higher adaptation abilities of young people and their conviction that current unemployment status has only a temporary character.

On the basis of the results of research in occupational psychology, it can be claimed that the broadly understood quality of interpersonal relations at work is an important factor in satisfaction with work and good mental and physical condition of an employee. Certainly, the strength of this correlation depends on the type of work. The specific features of the professions of a nurse and a midwife include the relations with colleagues, doctors and superiors. The positive influence of colleagues and superiors is especially important for mental and physical well-being.

The situation of unemployment alters the sphere of social contacts $[1,4]$. An unemployed person no longer feels wanted and his or her social role changes. The situation of unemployment typically brings stress, insecurity, aggression, depression or apathy, which largely influences social relations [28]. However, the outcomes of research in the group of nurses reveal that those who were working evaluated life quality in the social domain lower than those who were unemployed. Similarly, in the group of midwives, life quality in the social domain was rated lower by employed midwives and higher by the unemployed. The research conducted by Ergun also demonstrates that this domain is rated significantly lower by professionally-active nurses [26, 29].

The above-mentioned differences may result from overlapping of the mental and social domains which transfers psychical tiredness onto social relations and, consequently, risk of alienation [29], especially among single people [30]. Therefore, social support seems to be crucial, especially at work. This includes: feedback, advice and instructions improving effects of work, and praise. According to Ratajczak, such social support from superiors and colleagues is a factor highly conducive to a sense of satisfaction with work and life [31]. The authors' research seems to show that in the Polish realities, social support at work in the group of nurses and midwives is insufficient. On the other hand, the outcomes of the NEXT programme research indicate that in the professional environment of nurses in Poland the condition of interpersonal relations and social support can be regarded as satisfactory, in comparison with other examined countries [32].

Juxtaposition of the authors' results with outcomes achieved by other researchers was not easy due to few studies comparing the two groups - of professionally-active and inactive people.

This study attempted to discover the motives for the paradoxically higher evaluation of life quality in a group of unemployed people. Nevertheless, in order to determine the real reasons, it is necessary to continue the research, taking into account methods of qualitative evaluation.

\section{CONCLUSIONS}

1. Paradoxically, unemployed respondents made typically more positive evaluations of the examined phenomenon.

2. Employment is not a factor positively influencing quality of life and its psychosocial dimension.

3. Higher evaluation of life quality among unemployed respondents may result from the buffering impact of social support.

\section{REFERENCES}

1. Brzeziński J. Metodologiczny i etyczny kontekst badań nad jakością życia. In: Bańka A (ed.). Psychologiczne i pedagogiczne wymiary jakości życia. Częstochowa 1994. p.11-18.

2. Chańska W. Nieszczęsny dar życia: filozofia i etyka jakości życia w medycynie współczesnej. Wrocław 2009.

3. Chirkowska-Smolak T, Chudzicka A. Człowiek w społecznej przestrzeni bezrobocia. Poznań 2004.

4. Bańka A, Derbis R. Pomiar i poczucie jakości życia u aktywnych zawodowo oraz bezrobotnych. Poznań 1995.

5. Donovan A, Oddy M. Psychological aspects of unemployment. Jurnal Adolesc. 1982, 5: 15-30.

6. Wachowiak A. Praca zawodowa kobiet zamężnych a jakość ich życia w Polsce. In: Zagórski Z (ed.). Socjologiczne portrety grup społecznych: tom studiów i szkiców (II). Wrocław 2002. p.267-282. 
7. Manek AM. [Psychological issues of unemployment]. Przegląd psychologiczny. 1991; 36(1): 137-149 [in Polish].

8. Tomaszewski T. Psychologiczne problemy funkcjonowania człowieka. Katowice 1995.

9. Burdelak W, Pepłońska B. [Night work and health of nurses and midviwes - a review]. Med Pr. 2013; 64(3): 397-418, http://dx.doi. org $/ 10.13075 / \mathrm{mp} .5893 .2013 .0034$ [in Polish].

10. Burdelak W, Bukowska A, Krysicka J, Pepłońska B. Night work and health status of nurses and midwives. Cross-sectional study. Med Pr. 2012; 63(5): 517-529.

11. Almalki MJ, FitzGerald G, Clark M. Quality of work life among primary health care nurses in the Jazan region, Saudi Arabia: a crosssectional study. Hum Resour Health. 2012; 10(1): 30, http://dx.doi.org/ doi:10.1186/1478-4491-10-30.

12. Bytnar B. [The life quality of scrub nurses working in shifts]. Prz Med Uniw Rzesz. 2010; 2: 205-212 [in Polish].

13. Bilski B, Kandefer W. [Determinants of the locomotor system load and their health effects among midwives]. Med Pr. 2007; 58(1): 7-12 [in Polish].

14. Hall EM, Johnson JV. Depression in unemployed Swedish women. Soc Sci Med. 1988; 27(12): 1349-1355.

15. Su J, Weng H, Tsang $\mathrm{H}$, Wu J. Mental health and quality of life among doctors, nurses and other hospital staff. Stress and Health. 2009; 25: 423-430, http://dx.doi.org/doi: 10.1002/smi.1261

16. Jaracz K, Kalfoss M, Górna K, Bączyk G. Quality of life in Polish respondents: psychometric properties of the Polish WHOQOL - Bref Scand J Caring Sci. 2006; 20(3): 251-260.

17. Zagożdżon P, Ejsmont J. [Health-related quality of life in unemployed individuals]. Probl Hig Epidemiol. 2008; 89(4): 498-503 [in Polish].

18. Axelsson L, Andersson IH, Edén L, Ejlertsson G. Inequalities of quality of life in unemployed young adults: a population-based questionnaire study. Int J Equity Health. 2007; 6: 1, http://dx.doi.org/doi:10.1186/14759276-6-1

19. Leino-Loison K, Gien LT, Katajisto J, Välimäki M. Sense of coherence among unemployed nurses. J Adv Nurs. 2004; 48(4): 413-422.

20. Gholami A, Farsi M, Hashemi Z, Lotfabadi P. Quality of life in nurses working in Neyshabur hospitals. Thrita. 2013; 2(1): 94-100, http:// dx.doi.org/10.5812/thrita.7384.
21. Rios KA, Barbosa DA, Belasco AG. Evaluation of quality of life and depression in nursing technicians and nursing assistants. Rev Lat Am Enfermagem. 2010; 18(3): 413-20, http://dx.doi.org/10.1590/S010411692010000300017

22. Joslin LE, Davis CR, Dolan P, Clark EM. Quality of life and neck pain in nurses. Int J Occup Med Environ Health. 2014; 27(2): 236-242, http:// dx.doi.org/10.2478/s13382-014-0267-7

23. Hammarstrom A, Janlert U. Early unemployment can contribute to adult health problems: results from a longitudinal study of school leavers. J Epidemiol Community Health. 2002; 56(8): 624-630, http:// dx.doi.org/10.1136/jech.56.8.624

24. Kliszcz J, Nowicka-Sauer K, Trzeciak B, Sadowska A. [The level of anxiety, depression and aggression in nurses and their life and job satisfaction]. Med Pr. 2004; 55(6): 461-468 [in Polish].

25. Wysokiński M, Fidecki W, Walas L, Ślusarz R, Sienkiewicz Z, Sadurska A, et al. [Polish nurses' satisfaction with life]. Prob Pieleg. 2009; 17(3): 167-172 [in Polish].

26. Ergün FS, Oran NT, Bender CM. Quality of life of oncology nurses. Cancer Nurs. 2005; 28(3): 193-9.

27. Nakata Y, Miyazaki S. Non-working nurses in Japan: estimated size and its age-cohort characteristics. J Clin Nurs. 2008; 17(24): 3306-3316, http://dx.doi.org/10.1111/j.1365-2702.2008.02656.x

28. Aalaa M, Sanjari M, Tootee A, Mirzabeigi G, Salemi S. Assessment of quality of life of Iranian nurses. Nurs Rep. 2012; 1(2): 57-62, http:// dx.doi.org/10.4081/nursrep.2012.e10

29. Babiarczyk B, Fraś M, Ulman-Włodarz I, Jarosova D. [The level of job satisfaction and its relation to midwives' subjective quality of life]. Med Pr. 2014; 65(1): 99-108, http://dx.doi.org/10.13075/mp.5893.2014.011 [in Polish].

30. Sorić M, Golubić R, Milosević M, Juras K, Mustajbegović J. Shift work, quality of life and work ability among Croatian hospital nurses. Coll Antropol. 2013; 37(2): 379-84.

31. Ratajczak Z. Utrata pracy jako doświadczenie traumatyzujące i wyzwanie rozwojowe. In: Ratajczak Z (ed.). Psychologiczne problemy funkcjonowania człowieka w sytuacji pracy. Katowice 1995.

32. Ogińska H, Pokorski J. Deficyt snu, jego przyczyny i konsekwencje u pielęgniarek. Pielęgniarek polskich portret własny z Europą w tle, czyli raport z badań europejskiego projektu NEXT - materiały konferencyjne; 6 czerwca 2005, Warszawa, Polska. 